\title{
Pengaruh Perputaran Modal Kerja dan Perputaran Piutang Terhadap Profitabilitas Pada PT. Hanjaya Mandala Sampoerna Tbk
}

\author{
Mardiah $^{1)}$, Nafisah Nurulrahmatiah ${ }^{2)}$ \\ Prodi Manajemen Sekolah Tinggi Ilmu Ekonomi (STIE) Bima \\ Email: mardiah.stiebimaa16@gmail.com ${ }^{1)}$ \\ Email: nafisahrachmatia@gmail.com ${ }^{2)}$
}

\begin{abstract}
ABSTRAK
Penelitian ini bertujuan untuk mengetahui seberapa besar pengaruh perputaran modal kerja dan perputaran piutang terhadap profitabilitas pada PT. Hanjaya Mandala Sampoerna Tbk. Penelitian yang digunakan adalah melalui pendekatan metode deskriptif dan verifikatif dimana hasil dari penelitian tersebut menunjukkan bahwa besar kecilnya perputaran modal kerja dan perputaran piutang memiliki kontribusi terhadap perolehan laba.
\end{abstract}

Kata kunci : Perputaran modal kerja, Perputaran piutang, Profitabilitas

\begin{abstract}
ABSTARCT
This study aims to determine how much influence the working capital turnover and accounts receivable turnover on profitability at PT. Hanjaya mandala Sampoerna Tbk. The research used is through the descriptive and verification method approach where the results of the study indicate that the size of the working capital turnover and accounts receivable turnover have a contribution to profitability.
\end{abstract}

Keywords : Working Capital Turnover, Accounts Receivable Turnover, Profitability

\section{PENDAHULUAN}

Perusahaan memerlukan dana untuk melakukan kegiatan operasionalnya, dana tersebut disebut dengan modal kerja. Perusahaan harus memenuhi kebutuhan modal kerja jika kelebihan atau kekurangan mempengaruhi profitabilitas perusahaan. Perusahaan yang mempunyai modal kerja lebih besar dari kebutuhan akan mengakibatkan tidak efisien penggunaannya dan jika lebih kecil dapat mengganggu operasional perusahaan, (Satriya, 2014).

Perusahaan yang mampu menghasilkan nlai tambah atau keuntungan yang sustainable (keuntungan) adalah perusahaan yang mampu memanfaatkan modal kerjanya secara efektif dan efisien. Semakin tinggi perputaran modal kerja maka semakin efektif penggunaan modal kerja perusahaan, sebaliknya semakin rendah perputaran modal kerja semakin tidak efektif penggunaan modal kerja perusahaan sehingga menyebabkan terhambatnya kegiatan operasional perusahaan yang pada akhirnya akan menghambat kemampuan perusahaan dalam memperoleh keuntungan, (Santoso, 2013).

Piutang termasuk aktiva lancar yang mempengaruhi modal. Apabila jumlah investasi yang tertanam dalam piutang terlalu tinggi akan menimbulkan rendahnya perputaran modal kerja sehingga semakin kecil pula kemampuan perusahaan dalam meningkatkan volume penjualan. Berkurangnya volume penjualan akan berakibat pada berkurangnya laba yang akan diperoleh perusahaan, (Prakoso, 2014)

Profitabilitas yaitu kemampuan perusahaan dalam memperoleh laba dalam periode tertentu. Tingkat profitabilitas yang tinggi pada suatu perusahaan berarti tinggi pula efisiensi penggunaan modal yang digunakan oleh perusahaan tersebut. Maka setiap perusahaan akan berusaha untuk meningkatkan profitabilitasnya, karena semakin tinggi profitabilitas suatu perusahaan maka kelangsungan hidup perusahaan tersebut akan lebih terjamin, (Ananda, 2017).

Penelitian ini dilakukan pada PT. Hanjaya Mandala Sampoerna Tbk yang bergerak di industri rokok.. Dilihat dari laba yang diperoleh perusahaan ini mengalami fluktuatif selama 8 tahun terakhir. Hal ini terlihat dari menurunnya laba pada tahun 2014, kemudian ditahun 2015 dan 2016 laba kembali meningkat akan tetapi pada tahun 2017 laba kembali menurun, meskipun di akhir tahun 2018 laba kembali meningkat. Hal ini menunjukkan bahwa perusahaan 
belum mampu menghasilkan laba secara maksimal dari penggunaan modal yang belum efisien oleh perusahaan.

Penelitian ini sejalan dengan beberapa penelitian sebelumnya. Hal ini dibuktikan dengan Penelitian yang dilakukan oleh Pratiwi (2018) mengatakan bahwa perputaran modal kerja berpengaruh signifikan terhadap profitabilitas. Pada penelitian Rahayu (2014) mengatakan bahwa perputaran piutang tidak berpengaruh signifikan terhadap profitabilitas. Sedangkan pada penelitian Santoso (2013) mengatakan bahwa secara simultan terdapat pengaruh yang signifikan antara perputaran modal kerja dan perputaran piutang terhadap profitabilitas.

Perbedaan penelitian ini dengan penelitian sebelumnya terdapat pada lokasi, dan waktu penelitian. Penelitian ini dilakukan pada PT. Hanjaya Mandala Sampoerna Tbk pada tahun 2011 sampai dengan tahun 2018.

Penelitian merupakan suatu proses pencarian kebenaran ataupun pembuktian terhadap suatu fenomena melalui prosedur kerja tertentu. Adapun penulis melakukan penelitian ini dengan tujuan untuk mengetahui seberapa besar pengaruh perputaran modal kerja dan perputaran piutang terhadap profitabilitas pada PT. Hanjaya Mandala Sampoerna Tbk.

\section{TINJAUAN PUSTAKA}

\section{Modal Kerja}

Modal kerja adalah investasi jangka pendek atau disebut juga aset lancar diantaranya adalah kas, persediaan piutang, investasi jangka pendek dan biaya dibayar dimuka, (Prakoso, 2014).

Perputaran modal kerja adalah salah satu rasio untuk mengukur atau menilai keefektifan modal kerja perusahaan selama periode tertentu. Artinya seberapa banyak modal kerja berputar selama suatu periode atau dalam suatu periode. Semakin cepat perputaran modal kerja menunjukkan semakin efektif penggunaan modal kerja yang berdampak pada meningkatnya profitabilitas perusahaan, (Handayani, 2016). Rumus yang digunakan untuk mencari perputaran modal kerja adalah sebagai berikut:

$$
\text { Perputaran modal kerja }=\frac{\text { Penjualan bersih }}{\text { Modal kerja }} \rightarrow(1)
$$

\section{Piutang}

Piutang adalah bentuk penjualan yang dilakukan oleh suatu perusahaan dimana pembayarannya tidak dilakukan secara tunai namun bertahap, (Santoso, 2013).

Perputaran piutang bagi perusahaan sangatlah penting untuk diketahui karena semakin tinggi perputaran piutang maka piutang yang ditagih oleh perusahaan makin banyak. Sehingga akan memperkecil adanya piutang yang tidak tertagih dan memperlancar arus kas. Selain itu dengan adanya perputaran piutang maka akan dapat diketahui bagaimana kinerja bagian marketing dalam mencari pelanggan yang potensial membeli dan potensial membayar piutang, (Handayani, 2016). Rumus yang digunakan untuk mencari perputaran piutang adalah sebagai berikut:

$$
\text { perputaran piutang }=\frac{\text { Penjualan kredit }}{\text { rata-rata piutang }} \rightarrow(2)
$$

\section{Profitabilitas}

Profitabilitas adalah kemampuan yang dicapai oleh perusahaan dalam satu periode tertentu. Analisis profitabilitas bertujuan untuk mengukur kemampuan perusahaan dalam memperoleh laba, baik dalam hubungannya dengan penjualan, aset, maupun modal sendiri. Hasil profitabilitas dapat dijadikan sebagai tolak ukur ataupun gambaran tentang efektivitas kinerja manajemen ditinjau dari keuntungan yang diperoleh dibandingkan dengan hasil penjualan dan investasi perusahaan, (Pratiwi D 2018).

Dalam penelitian ini profitabilitas diukur menggunakan ROA. ROA adalah rasio yang digunakan perusahaan untuk mengukur kemampuan perusahaan dalam memperoleh keuntungan (laba) secara keseluruhan. (ROA) bertujuan untuk mengukur kemampuan perusahaan dalam mengelola aktiva yang dikuasainya untuk menghasilkan pendapatan. Semakin besar Return On Asset (ROA) semakin besar pula keuntungan yang diperoleh perusahaan dan semakin baik perusahaan tersebut dari segi penggunaan asset, (Piter Tiong, 2017).

$$
\text { ROA }=\frac{\text { Laba sebelum pajak }}{\text { Total aktiva }} \quad \rightarrow(3)
$$

\section{Kerangka Pemikiran}

PT. Hanjaya Mandala Sampoerna Tbk adalah perusahaan yang bergerak di industri rokok. Dimana dalam menjalankan aktivitas usahanya, perusahaan perlu memperhatikan profitabilitas. Profitabilitas merupakan masalah yang sangat penting bagi perusahaan dan profitabilitas juga digunakan sebagai acuan berhasil atau tidak suatu perusahaan yang dipimpin oleh pemimpin perusahaan juga bagi karyawan perusahaan apabila profitabilitas yang didapatkan perusahaan semakin tinggi maka terdapat peluang untuk melakukan peningkatan gaji para karyawan, (Putri, 2015).

Untuk mengetahui keberhasilan suatu perusahaan dalam memperoleh laba dapat dilihat dari kesuksesan dan kemampuan perusahaan menggunakan modal kerja secara produktif. Hal ini dikarenakan perputaran modal kerja merupakan hal yang penting dalam aktiva yang memang harus dikelola oleh perusahaan dengan efektif dan efisien, (Satriya, 2014).

Perputaran piutang menunjukkan periode terikatnya modal kerja dalam piutang dimana semakin cepat periode berputarnya menunjukkan semakin cepat 
perusahaan mendapatkan keuntungan dari penjualan kredit tersebut, sehingga profitabilitas perusahaan juga ikut meningkat, (Sufiana, 2012).

Berdasarkan uraian diatas, maka kerangka berpikir dalam penelitian ini dapat digambarkan sebagai berikut :

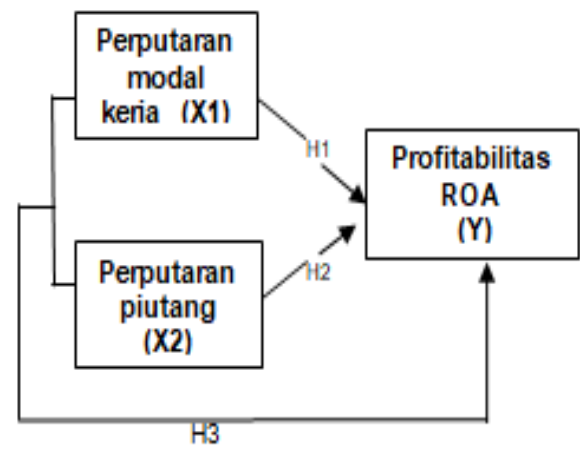

Gambar 1 Kerangka Pemikiran

\section{Hipotesis Penelitian}

Berdasarkan uraian diatas, maka hipotesis dalam penelitian ini adalah sebagai berikut:

1) Ada pengaruh yang signifikan secara parsial antara perputaran modal kerja terhadap profitabilitas

2) Ada pengaruh yang signifikan secara parsial antara perputaran piutang terhadap profitabilitas

3) Ada pengaruh secara simultan antara perputaran modal kerja dan perputaran piutang terhadap profitabilitas.

\section{METODE PENELITIAN}

Penelitian ini di lakukan pada PT. Hanjaya Mandala Sampoerna TBK yang beralamat di Jl. Rungkut Industri Raya No. 18, Surabaya, 60293, Indonesia. Website: www.sampoerna.com.

Populasi yang digunakan dalam penelitian ini yaitu berupa data laporan keuangan neraca terdiri atas aktiva lancar, hutang lancar, piutang, total aktiva dan rugi laba terdiri atas penjualan bersih dan laba sebelum pajak selama 28 tahun dari tahun 1990 sampai dengan tahun 2018.

Sampel yang digunakan dalam penelitian ini sebanyak 8 tahun dari tahun 2011 sampai tahun 2018. Teknik pengambilan sampel yang digunakan adalah teknik purposive sampling. Teknik purposive sampling adalah teknik penentuan sampel dengan alasan tertentu. Adapun pertimbangan penulis mengambil sampel selama 8 tahun terakhir yaitu untuk memudahkan penelitian dan sampel tersebut dianggap telah mewakili keseluruhan populasi.

Teknik pengumpulan data yang digunakan dalam penelitian ini berupa dokumentasi dan studi pustaka.
Teknik analisa data yang digunakan dalam penelitian ini yaitu uji asumsi klasik, regresi linear berganda, koefisien korelasi berganda, koefisien determinasi berganda, uji t dan uji f.

\section{HASIL DAN PEMBAHASAN}

\section{Uji asumsi klasik}

1. Uji normalitas, pengujian ini dilakukan untuk mengetahui normal tidaknya data sampel. Uji normalitas dalam penelitian ini menggunakan Grafik normal Probability Plot.

Normal P.P Plot of Regression Standardized Residual

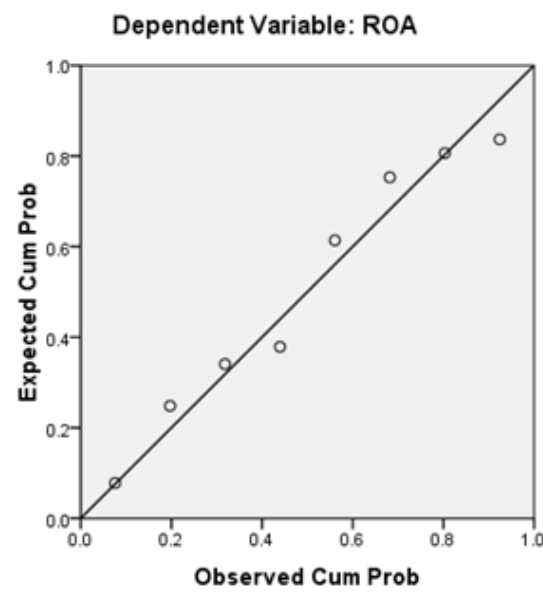

Gambar 2 Hasil Uji Normalitas

Grafik diatas mempertegas bahwa model regresi yang diperoleh berdistribusi normal, dimana sebaran data berada disekitar garis diagonal.

2. Uji Multikolinearitas, bertujuan untuk menguji apakah pada sebuah model regresi ditemukan adanya korelasi antar variabel independen. Jika terjadi korelasi maka dinamakan terdapat problem multikolinieritas.

Tabel 1, Uji Multikolinearitas

\begin{tabular}{cc}
\hline \multicolumn{2}{c}{ Collinearity Statistics } \\
\hline Tolerance & VIF \\
\hline .363 & 2.756 \\
.363 & 2.756 \\
\hline
\end{tabular}

Berdasarkan hasil olahan SPSS maka diperoleh nilai VIF sebesar 2,756 yang berarti VIF $<10$ dan tolerance sebesar 0,363 yang berarti tolerance > 0,1 maka dapat dinyatakan tidak terjadi multikolinieritas.

3. Uji heterokedastisitas, bertujuan untuk menguji apakah dalam model regresi terjadi ketidaksamaan varian atau residual satu pengamatan ke pengamatan lainnya. 


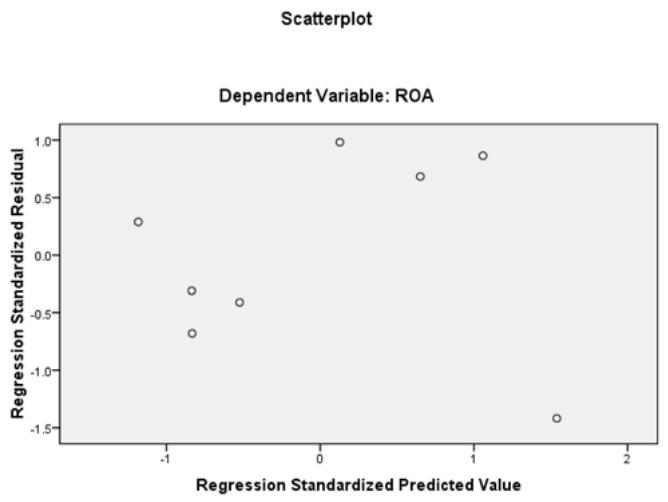

Gambar 3 Uji Heterokedastisitas

Berdasarkan hasil olahan SPSS terlihat bahwa tidak ada pola yang jelas serta titik-titik menyebar baik diatas maupun dibawah angka 0 pada sumbu Y, maka dapat disimpulkan bahwa tidak terdapat gejala heterokedastisitas pada model regresi yang digunakan.

4. Uji autokorelasi, bertujuan untuk menguji apakah dalam model regresi linear ada korelasi. Untuk mendeteksi ada atau tidaknya autokorelasi dilakukan uji Durbin-Watson.

Tabel 2. Uji Autokorelasi

\begin{tabular}{cccc}
\hline Model & $\begin{array}{l}\text { Std.Error of } \\
\text { The Estimate }\end{array}$ & $\begin{array}{l}\text { Durbin } \\
\text { Watson }\end{array}$ & Keterangan \\
\hline 1 & .048981 & 1.197 & $\begin{array}{c}\text { Bebas } \\
\text { Autokorelasi }\end{array}$ \\
\hline
\end{tabular}

Berdasarkan hasil olahan SPSS diketahui nilai DW sebesar 1,197 yang berarti $0,5591<2,803>1,7771$ maka dapat disimpulkan bahwa tidak terdapat gejala autokorelasi karena nilai DW berada diantara nilai dL dan dU.

\section{Regresi linear berganda}

Digunakan untuk menyatakan seberapa besar naik turunnya nilai variabel terikat terhadap dua atau lebih variabel bebas.

Tabel 3. Hasil Uji Regresi Linear Berganda

Coefficients $^{2}$

\begin{tabular}{lccccc}
\hline \multicolumn{1}{c}{ Model } & $\begin{array}{c}\text { Unstandardized } \\
\text { Coefficients }\end{array}$ & $\begin{array}{c}\text { Standardized } \\
\text { Coefficients }\end{array}$ & $\mathbf{t}$ & Sig \\
\hline 1. (Constant) & .077 & .294 & & .263 & .803 \\
& & & & & \\
Perputaran & .028 & .010 & 1.088 & 2.70 & .043 \\
Modal Kerja & & & & 3 & \\
$\begin{array}{l}\text { Perputaran } \\
\text { Piutang }\end{array}$ & .183 & .214 & .343 & .853 & .433 \\
& & & & & \\
\hline
\end{tabular}

a.Dependent Variable ROA

Sumber Data : Diolah dengan spss
Berdasarkan hasil olahan SPSS diatas dapat dirumuskan persamaan regresi linear berganda adalah:

$$
\mathrm{Y}=\mathbf{0 , 0 7 7}+\mathbf{0 , 0 2 8} \times 1+\mathbf{0 , 1 8 3} \times \mathbf{2} \rightarrow(4)
$$

1. Nilai Konstanta (a) sebesar 0,077, ini dapat diartikan jika perputaran modal kerja dan perputaran piutang nilainya 0 , maka profitabilitas nilainya adalah 0,077 .

2. Koefisien regresi perputaran modal kerja sebesar 0,028 artinya jika perputaran modal kerja mengalami kenaikan satu satuan maka Profitabilitas akan mengalami peningkatan sebesar 0,028 .

3. Koefisien regresi perputaran piutang sebesar 0,183 artinya jika variabel perputaran piutang mengalami kenaikan satu satuan maka profitabilitas akan mengalami peningkatan sebesar 0,183 .

\section{Uji koefisien korelasi berganda}

Merupakan ukuran keeratan hubungan antara variabel terikat dan semua variabel bebas.

Tabel 4. Hasil Uji Koefisien Korelasi

\begin{tabular}{ccccc}
\multicolumn{6}{c}{ Model Summary } \\
\hline Model & R & R Square & $\begin{array}{c}\text { Adjusted } \\
\text { R Square }\end{array}$ & $\begin{array}{c}\text { Std.Error } \\
\text { of the } \\
\text { Estimate }\end{array}$ \\
\hline 1 & $0840^{2}$ & .706 & .588 & .048981 \\
\hline
\end{tabular}

Predictors: (Constant), PERPUTARAN PIUTANG, PERPUTARAN MODAL KERJA

a. Dependent Variable: ROA

Berdasarkan tabel diatas, terlihat koefisien korelasi sebesar 0,840 atau $r=0,840$ angka tersebut menunjukkan korelasi yang sangat kuat karena berada pada rentang $0,80-1,00$.

\section{Uji Koefisien Determinasi Berganda,}

Digunakan untuk mengukur seberapa jauh kemampuan model dalam menerangkan variabel terikat.

Berdasarkan hasil olahan SPSS pada Tabel 4 dapat dilihat bahwa nilai R Square sebesar 0,706, artinya sumbangan pengaruh perputaran modal kerja dan perputaran piutang terhadap profitabilitas yang dilihat dari ROA adalah sebesar $70,6 \%$ sedangkan sisanya $29,4 \%$ dipengaruhi oleh variabel lain yang tidak diteliti dalam penelitian ini. 


\section{Uji t dan Uji f}

Tabel 5. Hasil Uji t

Model Summary Coefficients $^{2}$

\begin{tabular}{|c|c|c|c|c|c|c|c|}
\hline \multirow[b]{2}{*}{ Model } & \multicolumn{2}{|c|}{$\begin{array}{l}\text { Unstandardized } \\
\text { Coefficients }\end{array}$} & \multirow{2}{*}{$\begin{array}{c}\begin{array}{c}\text { Standardized } \\
\text { Coefficients }\end{array} \\
\text { Beta }\end{array}$} & \multirow[b]{2}{*}{$\mathrm{t}$} & \multirow[b]{2}{*}{ Sig } & \multicolumn{2}{|c|}{ Cpllinearity Statistics } \\
\hline & B & $\begin{array}{c}\text { Std } \\
\text { Enror }\end{array}$ & & & & Tolerance & VIF \\
\hline 1. (Constant) & .077 & .294 & & .263 & .803 & & \\
\hline $\begin{array}{l}\text { Perputaran Modal } \\
\text { Kerja }\end{array}$ & .028 & .010 & 1.088 & 2.703 & .043 & .363 & 2.756 \\
\hline $\begin{array}{l}\text { Perputaran } \\
\text { Piutang }\end{array}$ & .183 & .214 & .343 & .853 & .433 & .363 & 2.756 \\
\hline
\end{tabular}

Sumber Data : Diolah Dengan SPSS

1. Variabel perputaran modal kerja, diperoleh nilai $\mathrm{t}_{\text {hitung }}$ sebesar 2,703 dan tingkat signifikan sebesar 0,043, kemudian dibandingkan dengan $t_{\text {tabel }}$ sebesar 2,571, jadi nilai $t_{\text {hitung }}>t_{\text {tabel }}(2,703>$ 2,571) dengan signifikansi $0,043<0,05$ maka dapat disimpulkan bahwa terdapat pengaruh signifikan antara perputaran modal kerja terhadap ROA.

2. Variabel perputaran piutang, diperoleh nilai $t_{\text {hitung }}$ sebesar 0,853 dan tingkat signifikan sebesar 0,433 kemudian dibandingkan dengan $t_{\text {tabel }}$ sebesar 2,571, jadi nilai $t_{\text {hitung }}<t_{\text {tabel }}(0,853<2,571)$ dengan signifikansi $0,433>0,05$ maka dapat disimpulkan tidak terdapat pengaruh signifikan antara perputaran piutang terhadap ROA.

Tabel 6. Hasil Uji f

\begin{tabular}{|c|c|c|c|c|c|}
\hline Model & $\begin{array}{c}\text { Sum of } \\
\text { Squares }\end{array}$ & df & $\begin{array}{c}\text { Mean } \\
\text { Squares }\end{array}$ & $\mathbf{F}$ & Sig \\
\hline 1 Regression & .029 & 2 & 0.14 & 6.001 & $.047^{2}$ \\
\hline Residual & .012 & 5 & .002 & & \\
\hline Total & .041 & 7 & & & \\
\hline
\end{tabular}

a. Predictor (Constant), PERPUTARAN PIUTANG,

PERPUTARAN MODAL KERJA

b. Dependent Variable ROA

Sumber Data : Diolah Dengan SPSS

Berdasarkan tabel 6. Di atas diperoleh nilai $\mathrm{f}_{\text {hitung }}$ sebesar 6,001 dengan tingkat signifikan sebesar 0,047 dan nilai $\mathrm{f}_{\text {tabel }}$ diperoleh sebesar 5,786. sehingga nilai $\mathrm{f}_{\text {hitung }}>\mathrm{f}_{\text {tabel }}(6,001>5,786)$ dengan signifikansi 0,047 $<0,05$ dengan demikian dapat diketahui bahwa perputaran modal kerja dan perputaran piutang berpengaruh signifikan terhadap ROA.

\section{Pengaruh Perputaran Modal Kerja (X1) Terhadap Profitabilitas (Y)}

Variabel perputaran modal kerja (X1) memiliki pengaruh yang signifikan terhadap profitabilitas (Y). Hal ini menunjukkan bahwa perubahan perputaran modal kerja mengakibatkan perubahan pada profitabilitas. Semakin cepat perputaran modal kerja maka semakin banyak penjualan yang berhasil dilakukan dan semakin besar keuntungan yang dapat diraih perusahaan sehingga dapat meningkatkan profitabilitas. Penelitian ini juga didukung oleh penelitian Pratiwi, (2018) bahwa perputaran modal kerja berpengaruh signifikan terhadap profitabilitas.

Hasil penelitian ini juga didukung oleh penelitian Satriya (2014) bahwa perputaran modal kerja berpengaruh signifikan terhadap profitabilitas. Perusahaan menggunakan modal kerja untuk kegiatan operasionalnya. Dana yang dikeluarkan perusahaan diharapkan kembali untuk kegiatan operasional perusahaan selanjutnya. Hasil tersebut membuktikan bahwa semakin tinggi volume penjualan yang dihasilkan maka modal kerja berputar semakin cepat sehingga modal cepat kembali ke perusahaan yang disertai keuntungan yang tinggi pula.

\section{Pengaruh Perputaran Piutang (X2) Terhadap Profitabilitas (Y)}

Dari hasil penelitian ini dapat diketahui bahwa perputaran piutang tidak berpengaruh signifikan terhadap profitabilitas. Perputaran piutang yang tinggi dapat meningkatkan profitabilitas, karena jumlah piutang tak tertagih semakin sedikit. Namun piutang yang teralu tinggi juga dapat menurunkan profitabilitas. Hal ini mengindikasikan bahwa piutang yang terlalu tinggi dapat menurunkan profitabilitas karena jumlah piutang yang dimiliki sedikit berarti penjualan kredit yang dilakukan perusahaan sedikit, sehingga volume penjualan juga akan turun dan pada akhirnya profitabilitas perusahaan ikut menurun. Penelitian ini didukung oleh penelitian Rahayu, (2014) bahwa perputaran piutang tidak berpengaruh signifikan terhadap profitabilitas.

Hasil penelitian ini juga didukung oleh penelitian Nurafika (2018) bahwa perputaran piutang tidak berpengaruh signifikan terhadap profitabilitas. Hal yang menyebabkan perputaran piutang tidak berpengaruh signifikan yaitu tingkat perputaran piutang yang terlalu rendah dan membutuhkan waktu yang lama untuk dapat ditagih dalam bentuk uang tunai, penjualan kredit yang dilakukan perusahaan juga sedikit sehingga penjualan menurun dan menyebabkan profitabilitas perusahaan juga menurun. Syarat pembayaran piutang juga menjadi salah satu faktornya, karena jika pembayaran lunak akan mengakibatkan jumlah piutang semakin besar tetapi perputaran piutang justru semakin rendah. Dan jika syarat pembayarannya ketat akan mengakibatkan jumlah piutang rendah dan perputaran piutangnya akan semakin tinggi. Hal inilah yang menyebabkan perputaran piutang tidak berpengaruh signifikan terhadap profitabilitas perusahaan.

\section{Pengaruh Perputaran Modal Kerja (X1) dan Perputaran Piutang (X2) Terhadap Profitabilitas (Y)}

Hasil penelitian dapat diketahui bahwa secara simultan dari kedua variabel bebas yang diteliti yaitu 
perputaran modal kerja dan perputaran piutang memiliki pengaruh terhadap profitabilitas. Hal ini dibuktikan bahwa perputaran modal kerja dan perputaran piutang berpengaruh terhadap ROA sebesar 70,6\% sedangkan $29,4 \%$ dipengaruhi oleh variabel lain yang tidak diteliti dalam penelitian ini. Hal ini juga menunjukkan bahwa besar kecilnya perputaran modal kerja dan perputaran piutang memiliki kontribusi terhadap perolehan laba pada PT. Hanjaya Mandala Sampoerna Tbk. Penelitian ini didukung oleh penelitian Santoso, (2013) bahwa perputaran modal kerja dan perputaran piutang secara simultan berpengaruh terhadap profitabilitas.

\section{SIMPULAN DAN SARAN}

\section{Simpulan}

Berdasarkan hasil penelitian maka dapat diambil kesimpulan sebagai berikut :

1. Perputaran modal kerja secara parsial berpengaruh signifikan terhadap ROA. Hal ini menunjukkan semakin cepat perputaran modal kerja maka semakin banyak penjualan yang berhasil dilakukan dan semakin besar keuntungan yang dapat diraih perusahaan sehingga dapat meningkatkan profitabilitas

2. Perputaran piutang secara parsial tidak berpengaruh signifikan terhadap ROA, karena perputaran piutang yang terlalu tinggi dapat menurunkan profitabilitas

3. Perputaran modal kerja dan perputaran piutang berpengaruh dan signifikan terhadap ROA. Hal ini juga menunjukkan bahwa besar kecilnya perputaran modal kerja dan perputaran piutang memiliki kontribusi terhadap perolehan laba.

\section{Saran}

Berdasarkan hasil kesimpulan, maka penelitian memberikan saran, sebagai berikut :

1. Perusahaan diharapkan dapat lebih memaksimalkan penggunaan modal dan mempercepat perputaran piutang agar modal yang tertanam pada piutang dapat diolah untuk memenuhi kebutuhan perusahaan dan dapat menghasilkan laba secara maksimal agar investor tertarik untuk berinvestasi pada perusahaan tersebut.

2. Bagi peneliti selanjutnya, sebaiknya tidak hanya menggunakan variabel perputaran modal kerja dan perputaran piutang saja tetapi bisa juga menggunakan rasio keuangan lain terutama yang mempunyai hubungan terhadap profitabilitas. Perluasan sampel dan menambah periode penelitian juga dapat dilakukan pada penelitian selanjutnya agar hasilnya lebih akurat.

\section{DAFTAR PUSTAKA}

Ananda, AN dan Ibrahim, M. (2017). Pengaruh Perputaran Modal Kerja Dan Perputaran Piutang Terhadap Profitabilitas. Jurnal Online Mahasiswa Fakultas Ilmu Sosial Dan Ilmu Politik Universitas Riau, 4(2): 1-14.

Handayani, T., Kristianto, D., dan Astuti, D.S.P. (2016). Pengaruh Perputaran Modal Kerja, Perputaran Piutang Dan Perputaran Kas Terhadap Profitabilitas. Jurnal Akuntansi dan Sistem Teknologi informasi, 12(2): 259-265.

Nurafika, R. A. (2018) Pengaruh Perputaran Kas, Perputaran Piutang, Perputaran Persediaan Terhadap profitabilitas Pada Perusahaan Semen. Jurnal Akuntansi Dan Bisnis, 4(1): 98-101.

Prakoso, B. (2014). Pengaruh Perputaran Modal Kerja Dan Perputaran Piutang Terhadap Profitabilitas. Jurnal Administrasi Bisnis, 15(1): 1-9.

Pratiwi, D. (2018). Pengaruh Perputaran Modal Kerja, Perputaran Piutang Dan Perputaran Persediaan Terhadap Profitabilitas Pada Perusahaan Industri Barang Konsumsi di Bursa Efek Indonesia. Jurnal Ilmu Manajemen, 7(1): 77-89.

Pratiwi, F.W.N., Abdullah, M. F., dan Suliswanto, M. S. W. (2018). Pengaruh Perputaran Modal Kerja, Perputaran Piutang Dan perputaran Total Aset Terhadap Profitabilitas. Jurnal Ilmu Ekonomi, 2(2): 191-193.

Putri, P. I. G., \& Sudiartha, G. M. (2015). Pengaruh Modal Kerja Terhadap Profitabilitas Perusahaan Food And Beverages. E-Jurnal manajemen, 4(2): 511-523.

Santoso, C.E. (2013). Perputaran modal kerja dan perputaran piutang pengaruhnya terhadap profitabilitas. Jurnal EMBA: Jurnal Riset Ekonomi, Manajemen, Bisnis Dan Akuntansi, 1(4): 1581-1590.

Satriya, I. M. D., \& Lestari, P. V. (2014). Pengaruh Perputaran Modal Kerja Terhadap Profitabilitas Perusahaan. E-Jurnal Manajemen, 3(7):19271942.

Sufiana, N., dan Purnawati, N. K. (2012). Pengaruh Perputaran Kas, Perputaran Piutang Dan Perputaran Persediaan Terhadap Profitabilitas. Jurnal Ekonomi.

Sugiyono. (2012). Metode Penelitian Kuantitatif Kualitatif Dan R\&D. Bandung: Alfabeta.

Tiong, Piter. (2017). Pengaruh Perputaran Piutang Terhadap Profitabilitas. Journal Of Management And Busines, 1(1): 1-25. 